\title{
Screening of certain chilli germplasm against yellow mite, Polyphagotarsonemus latus (Banks)
}

\author{
S. BHATTACHARJEE* AND S. RAHMAN \\ Department of Entomology, Assam Agricultural University, JORHAT (ASSAM) INDIA
}

\section{ARITCLE INFO}

Received : 14.03 .2017

Revised : 17.08 .2017

Accepted : 29.08.2017

\section{KEY WORDS :}

Screening, Polyphagotarsonemus latus, Chilli germplasm
*Corresponding author:

Email : snigdhabhattacharjee06 @ gmail.com

\begin{abstract}
:
An experiment was conducted during the year 2012 and 2013 to screen out 30 chilli germplasm against yellow mite, Polyphagotarsonemus latus (Banks). Out of 30 chill germplasms, 7 germplasms viz., 13/09, 10/09, 7/09, CH/09/8A3, 11/CHIVAR-6, 10/CHIVAR6,10/CHIVAR-3 were found to be resistant as they were found free of mite infestation and leaf curl symptoms. Entries LCA-334, ASC-06-1, KA-2, BH10/04, VR-338, CHIVAR5, CHIVAR-7, 11/CHIVAR-7, G-8B, G-5B, G-3, G-1, 17/09, 5/A/09, BH10/04 and Mem jolokia were found to be moderately resistant with a damage score of 0.2 to 1.4 showing about 25 per cent leaf curling. The entries 15/02, G-2 and CHIVAR-4 showed a damage score of 2.4, 2.7 and 2.29 and per cent leaf curling of $44.23,46.53$ and 29.28, respectively and were recorded as moderately susceptible. Whereas 11/ CHIVAR-1 recorded the highest damage with damage score 3.6, showing 90.48 per cent leaf curling followed by Bhut jolokia and Pusa Juwala which were found to be highly susceptible showing around 82.2 to 89.7 per cent leaf curling with damage score 3.5 and 3.4, respectively.
\end{abstract}

How to view point the article : Bhattacharjee, S. and Rahman, S. (2017). Screening of certain chilli germplasm against yellow mite,_Polyphagotarsonemus latus (Banks) . Internat. J. Plant Protec., 10(2) : 320-323, DOI : 10.15740/HAS/IJPP/10.2/320-323. 